\title{
Supplying Spin-Offs: Collaboration Practices in the Perpetuation of an Organization
}

\section{Katja Maria Hydle and Kjersti Vikse Meland ${ }^{2}$}

\begin{abstract}
This paper focuses on the collaboration practices between spin-offs and their customers and suppliers. With empirical material from seven cases of incumbentbacked spin-offs, we find that suppliers are highly involved in the development of the innovation that spin-offs are based upon and specifically, the practices of understanding customers, identifying a market gap and collaborating with suppliers. We contribute to the spin-off literature by revealing which activities are at play for successful spin-offs, and we contribute to practice theory by empirically uncovering the general understandings in the perpetuation of an organization and the nets between the spin-offs and their suppliers.
\end{abstract}

Keywords: corporate spin-offs, customers, suppliers, practices, general understandings.

\section{INTRODUCTION}

Business relations, such as customers, suppliers and strategic partners, represent the potential for increased value creation, and learning and innovation. This paper explores spin-offs and their relations to the external environment. A spin-off is understood to be a new organization that is formed by a split from another organization (Wallin, 2012). In the spin-off literature, there is a clear distinction between university or academic spin-offs (De Cleyn \& Braet, 2010; Rasmussen, Mosey \& Wright, 2011) and corporate spinoffs (Bergh, Johnson \& Dewitt, 2008; Bergh \& Lim, 2008; Bruneel, Van de Velde \& Clarysse, 2013; Clarysse, Wright \& Van de Velde, 2011). Our focus is on corporate spin-offs. Inspired by Chesbrough (2002) and Clarysse et al. (2011), we understand spin-offs as new legal entities created to develop and commercialize products or services based on either technologies belonging

1 Katja Maria Hydle, Ph.D., Senior Research Scientist, International Research Institute of Stavanger (IRIS), Oslo Science Park, Gaustadalleen 21, 0349 Oslo, Norway, tel. +47 930058 48. E-mail: katja.hydle@iris.no.

2 Kjersti Vikse Meland, Senior Research Scientist, Polytec, Sørhauggata 128, 5527 Haugesund, Norway, tel. +47 909 81 036. E-mail: kjersti.vikse.meland@polytec.no. 
to the 'parent' firm and/or opportunities identified when working for the parent company. The new firm, we designate as the 'child' firm, whereas the established firm is called the parent firm. We focus on incumbent-backed spin-offs, which result from the exploitation of an opportunity by employees, and on parent-backed spin-offs, which are initiated by parent firms (Bruneel et al., 2013).

Existing research on corporate spin-offs suggests that spin-offs occur when the external environment is strong for spinning off (Hellmann, 2007). According to Hellmann, the external entrepreneurial environment complements a firm's internal innovation and finds that employee-driven innovation can be taken advantage of through spin-offs if there is a strong external entrepreneurial environment. However, what a particularly good or strong external environment consists of is not discussed. Since spin-offs are dependent on the external environment, understanding how customers and suppliers are related to the spin-off is therefore important. The corporate spinoff literature draws primarily on the financial field for information concerning shareholder wealth and stock markets, and on the entrepreneurship and innovation field for innovation, start-ups, research and development and technology (Wallin, 2012). In corporate spin-off literature, there is thus little emphasis on the relation between customers and suppliers, which is concerning. However, there are many research streams available with respect to this relation.

Research on customer co-creation and interaction has been studied from two main perspectives: i) a supplier perspective in which researchers have taken a supplier perspective and emphasized customer participation (Jaakkola \& Halinen, 2006; Mills, Chase \& Margulies, 1983), and ii) a buyer perspective in which the interest has been focused on the involvement of suppliers in $\mathrm{R}$ \& D and product improvements (Chien \& Chen, 2010; Handfield, 1999; Wasti \& Liker, 1997). In the literature on supplier involvement, which is primarily based on research on new product development (Chien \& Chen, 2010; Handfield, 1999; Wasti \& Liker, 1997), supplier influence on design, which can be achieved through information sharing, suggestions or participation, has been noted as an important dimension in the evaluation of involvement (Wasti \& Liker, 1997). These different perspectives on customer co-creation and supplier involvement for innovation are highly relevant but are not highlighted in relation to spin-offs in particular. Spin-offs are, by definition, spun off to further develop products or services that were identified when working for the parent company. Although innovation is part of the reason why firms are spun off, we cannot assume that research on customer cocreation and supplier involvement for innovations are directly applicable to 
spin-offs. We therefore ask the following research question: How do spin-offs relate to customers and suppliers?

To view how customers and suppliers are part of a spin-off, we turn to practice theory to capture what is actually done (Schatzki, 2006). Practice theory is found to be useful for viewing the enacted entrepreneurial activities (Johannisson, 2011, 2012, 2014; Keating, Geiger \& McLoughlin, 2014; Steyaert \& Landström, 2011). This article uses practice theories in organization studies, which are powerful lenses with which to view spin-offs as organizations as they occur (Schatzki, 2005; Schatzki, 2006; Schatzki, Knorr Cetina \& von Savigny, 2001). This article, with a focus on external relations with customers and suppliers, has a twin paper that explores the internal relations between parent and child firms; these papers complement each other in exposing the practices for successful spin-offs.

Our study contributes to the existing literature as follows. First, we add to the innovation literature by examining how knowledge regarding customers and collaboration with suppliers influences spin-offs. We provide new insights into corporate entrepreneurship research by focusing our analysis on the spin-off level rather than solely on the parental level (Clarysse et al., 2011). Furthermore, we contribute to practice theory by empirically exploring how networks are important during the occurrences of an organization.

\section{LITERATURE REVIEW}

Drawing on the innovation field to understand corporate spin-offs, we first turn to product innovation. In the literature on product innovation, Danneels (2002) claims that firms developing new products need simultaneous competences that relate to both technology and customers. Customer competence is understood as the knowledge of customer needs and processes, distribution and sales channels, communication channels and company/brand reputation (Danneels, 2002). Customer focus is emphasized as key to enhancing innovation and enabling firms to sustain their competitive advantage in diverse research fields, such as strategy (Fjeldstad, Snow, Miles \& Lettl, 2012; Foss, Laursen \& Pedersen, 2011) and innovation (Chesbrough, 2003; Chesbrough, 2006). An understanding of open innovation emphasizes that customer co-creation and supplier relations are important parts of innovation (Chesbrough, 2003; Chesbrough, 2011; Chesbrough \& Crowther, 2006). The term 'open innovation' was introduced by H.W. Chesbrough (2003) who asserted that this approach would reduce innovation costs and time. Another research stream (Baldwin \& von Hippel, 2011) divides it among innovations by i) a single-user individual or a single firm that creates an innovation to use it, ii) the producer or firm wants to profit from its product 
by selling it to others, and iii) open collaborative projects in which the contributors share the work (Baldwin \& von Hippel, 2011). The researchers find that producer innovation without collaboration will be displaced by individual user innovation and open collaborative innovation (Baldwin \& von Hippel, 2011). These insights are highly relevant for spin-offs since they begin from the firm and have an innovation output with varying degrees of collaboration with the external environment.

With an emphasis on the collaboration with the external environment, research on interorganizational collaborations is also relevant (Levina, 2005; Levina \& Vaast, 2005). Interorganizational collaboration involves the development of shared practices between the participating firms (Levina \& Vaast, 2008). Differences in organizational contexts are found to be mediated through shared organizational practices that have been developed (Levina \& Vaast, 2008). These shared practices were created around joint development work and enabled participants to identify with one another and with their shared work (Levina \& Vaast, 2008, p. 320). However, the research stream is young and based on the work of only a few researchers (Berends, van Burg \& van Raaij, 2011; Levina \& Vaast, 2005; Sydow, Windeler, Schubert \& Möllering, 2012). Thus, to capture how successful spin-offs relate to customers and suppliers, we use practice theory to identify the activities involved.

Practice theory views practices as a set of organized activities (Schatzki, 2010, 2012; Schatzki et al., 2001). Practices are social phenomena in which multiple people participate. According to Schatzki (2005), a practice involves: i) practical understandings of the actions that are part of the practice, ii) rules or instructions, iii) teleological-affective structures that are acceptable for participants to use, and iv) general understandings of the work to be performed and the interaction involved. Because we want to focus on the interaction with others and the understanding of the work that is performed, the general understanding of practices is highly relevant. General understanding is referred to as the tact, courtesy, treatment of third persons, and matters germane to those specific practices (Schatzki, 2010). To understand an organization, it is necessary to view the actions that form it and the material arrangements in which those actions are performed. Although we focus on the practices of the spin-off and the external relations, we do not focus on the workings of an established organization; we aim at the origin and the perpetuation required to make the organization come about (Schatzki, 2005). The general understanding for an organization to occur is so far solely explained in relation to practice emergence as "the distillation of common general understandings" (Schatzki, 2013, p. 37). To view the perpetuation of an organization, it is necessary to identify other nets to which the organization is closely tied: 
"To grasp the ties among these nets is to study, among other things, commonalities and orchestration in their actions, teleological orders, and rules; chains of action, including harmonious, competitive, and confliction interactions; material connections among nets; and the desires, beliefs, and other attitudes that participants in one net have towards to other nets. (Schatzki, 2005, p. 476)".

In other words, we will need to uncover the actions and activities directed to customers and suppliers or those between the spin-offs and their customers and suppliers. We will use these insights from practice theory regarding the general understandings and the nets to which the spin-offs are tied.

\section{RESEARCH METHODS}

To view how spin-offs relate to customers and suppliers, we wanted to identify the interactions between them. We performed a collective case study with 7 spin-off cases (Silverman, 2005). This study is based on empirical case materials derived from 25 interviews in 7 cases of spin-offs dated from 2013 and 2014 in the south-western part of Norway. Each spin-off case involves interviewing representatives from both the parent firm and the spin-off. We conducted semi-structured theory-informed interviews on spin-off processes, inquiring about their practices and activities, with an interview guide for the parent firms and one for the child firms. For every case, the objective was to interview all those involved in the spin-off process; however, it soon occurred to us that there were not that many people involved. Hence, we interviewed the CEO or the strategic manager behind the spin-off from both the parent and child firm. During the interviews, we were informed about external persons who had been important during certain spin-offs, which caused us to enlarge the interview scope for those cases to include interviews with a third party such as investors, board members, customers or suppliers, who had closely followed the spin-off process. The unit of analysis is the practices from the idea to full realization of the spin-off. When studying spin-offs, we investigated them from idea to establishment with respect to the internal and external actors involved, the activities involved, the use of innovation processes such as stage-gate processes, the access to financial support, the use of established or emergent networks, the experience needed, and the knowledge and capabilities involved. We followed a semi-structured interview guide, and each interview lasted between one and two hours. The interviews were recorded and transcribed. To preserve anonymity, we identify the cases with the numbers 1 to 7 and explain whether the interviews stems from parent or child firm or from a third party (Table 1). 
Table 1. Overview of interviews in parent and child firms and third-party interviews

\begin{tabular}{llll}
\hline Spin-offs & Parent firm interviews & Child firm interviews & Third-party interviews \\
\hline 1 & 2 & 1 & 2 \\
2 & 1 & 1 & 1 \\
3 & 2 & 2 & \\
4 & 1 & 1 & 1 \\
5 & 2 & 1 & 1 \\
6 & 1 & 1 & 1 \\
7 & 2 & 1 & \\
7 Spin-offs & 11 interviews & 8 interviews & 6 interviews \\
\hline
\end{tabular}

The 7 cases are incumbent-backed spin-offs in oil and gas, maritime, and information and communication technologies (ICT). Table 2 provides an overview of the cases, where we understand spin-off success as still being operational and in business. Case 2 is a spin-off that remains in progress, whereas Case 5 was a spin-off that was terminated and the spin-off child firm was closed; however, the employees of the child firm returned to the parent firm (Table 2).

Table 2. Overview of the different cases of parent and spin-off companies

\begin{tabular}{llllll}
\hline $\begin{array}{l}\text { Case } \\
\text { Parent } \\
\text { company } \\
\text { established }\end{array}$ & $\begin{array}{l}\text { Spin-off } \\
\text { established }\end{array}$ & $\begin{array}{l}\text { No of employees } \\
\text { in 2014 }\end{array}$ & Revenues & Spin-off success \\
\hline 1 & 1966 & 2012 & 20 & Positive results & Yes \\
2 & 2010 & 2014 & 2 & Not yet & On-going \\
3 & 1987 & 2004 & 30 & Positive results & Yes \\
4 & 1979 & 2004 & 10 & Positive results & Yes \\
5 & 1973 & 2012 & None & Positive results & No (Dissolved 2013) \\
6 & 1999 & 2013 & 20 & Positive results & Yes \\
7 & 1948 & 2006 & 33 & Positive results & Yes \\
\hline
\end{tabular}

The analysis was conducted in several steps. We used an iterative strategy going back and forth between the empirical material and theories, called mystery construction (Alvesson \& Kärreman, 2007, 2011), and also referred to as abduction (Pierce, 1978). According to Alvesson and Kärreman (2007), there are three steps for this strategy: applying a theory, being surprised by empirical findings and phenomena that are not addressed in the theory and articulating a new theory intended to resolve the surprise found. First, the data were examined in relation to the research question - how do spinoffs relate to customers and suppliers? - with specific consideration for the activities related to customers and suppliers. During the interviews and data analysis, we found that supplier involvement was considerable in relation 
to the spin-offs and the development of the spin-off's product, technology, services and systems. Thus, we were surprised when we identified how much collaboration there was between the spin-off and their suppliers. Iterating between in-depth analysis of the empirical findings from each spin-off case and comparisons across the spin-off cases, and connections to the literature (Alvesson \& Kärreman, 2007), we thus returned to the literature and found different characteristics of collaboration for innovation, collaboration practices and practices involving nets. Across the cases, the general understandings of the customers and the market gap to fill were surprisingly similar, and we did not find differences related to industries, which is why we do not focus on those related industries. Thus, we categorized our collected material according to the emerging themes of understanding customers, identifying market gaps and collaborating with suppliers. This information is reported in the Findings and further analysed in the Discussion and Conclusions.

\section{ANALYSIS/STUDY}

Our findings indicate that successful spin-offs are a result of: i) understanding customers' or customer's customers' needs, ii) identifying a gap in the market, and iii) collaborating with suppliers to develop and test prototypes (Table 3).

Table 3. Cases in relation to their customers and suppliers

\begin{tabular}{|c|c|c|c|c|}
\hline Case & Customers' needs & Market gap & $\begin{array}{l}\text { Suppliers' } \\
\text { collaboration }\end{array}$ & $\begin{array}{l}\text { Successful } \\
\text { Spin-off }\end{array}$ \\
\hline 1 & $\begin{array}{l}\text { Understanding customers' } \\
\text { technical needs based } \\
\text { on senior personnel with } \\
\text { lengthy experience in } \\
\text { industry }\end{array}$ & $\begin{array}{l}\text { Delivering complete } \\
\text { and tailor-made ship } \\
\text { bridge solutions }\end{array}$ & $\begin{array}{l}\text { Collaboration with } \\
\text { suppliers with whom } \\
\text { they have a long- } \\
\text { term relationship }\end{array}$ & Yes \\
\hline 2 & $\begin{array}{l}\text { Understanding customers' } \\
\text { needs through understanding } \\
\text { their businesses and lengthy } \\
\text { experience from working in } \\
\text { the industry }\end{array}$ & $\begin{array}{l}\text { Need for a } \\
\text { tailor-made and } \\
\text { online business } \\
\text { management system. } \\
\text { A new type of online } \\
\text { platform with both } \\
\text { standard and tailor- } \\
\text { made modules }\end{array}$ & $\begin{array}{l}\text { Not applicable yet } \\
\text { because they are still } \\
\text { exploring customer } \\
\text { needs through pilot } \\
\text { customers and } \\
\text { internal use and are } \\
\text { in the process of } \\
\text { spinning off }\end{array}$ & Ongoing \\
\hline 3 & $\begin{array}{l}\text { Some employees had earlier } \\
\text { been employed by the spin-off } \\
\text { company's largest customer. } \\
\text { Spin-off firm established } \\
\text { because two customers } \\
\text { wanted to outsource their } \\
\text { engineering services. } \\
\text { Therefore, employees have } \\
\text { strong knowledge regarding } \\
\text { customer needs }\end{array}$ & $\begin{array}{l}\text { Localization of } \\
\text { department } \\
\text { offices close to } \\
\text { industrial and public } \\
\text { customers in rural } \\
\text { areas. The plan and } \\
\text { area consultancy } \\
\text { companies are often } \\
\text { located in cities }\end{array}$ & $\begin{array}{l}\text { Spin-off selling } \\
\text { complete plan } \\
\text { \& aerial services } \\
\text { collaborating with } \\
\text { suppliers to offer } \\
\text { more services that } \\
\text { are specialized } \\
\text { such as radon } \\
\text { measurement }\end{array}$ & Yes \\
\hline
\end{tabular}




\begin{tabular}{|c|c|c|c|c|}
\hline Case & Customers' needs & Market gap & $\begin{array}{l}\text { Suppliers' } \\
\text { collaboration }\end{array}$ & $\begin{array}{l}\text { Successful } \\
\text { Spin-off }\end{array}$ \\
\hline 4 & $\begin{array}{l}\text { Understanding customers' } \\
\text { technological needs and } \\
\text { difficulties of implementation } \\
\text { and the need for new } \\
\text { technologies }\end{array}$ & $\begin{array}{l}\text { The technology is } \\
\text { needed worldwide } \\
\text { within offshore }\end{array}$ & $\begin{array}{l}\text { Daily operational } \\
\text { collaboration }\end{array}$ & Yes \\
\hline 5 & $\begin{array}{l}\text { Understanding that } \\
\text { customers need integrated } \\
\text { rig services }\end{array}$ & $\begin{array}{l}\text { A need for locally } \\
\text { positioned services } \\
\text { for the offshore rig } \\
\text { market }\end{array}$ & $\begin{array}{l}\text { Did not work in } \\
\text { a collaborative } \\
\text { manner. Issues } \\
\text { unresolved }\end{array}$ & No \\
\hline 6 & $\begin{array}{l}\text { Understanding how } \\
\text { customers and end } \\
\text { customers need new services } \\
\text { and products }\end{array}$ & $\begin{array}{l}\text { A need for elderly to } \\
\text { be more secure at } \\
\text { home }\end{array}$ & $\begin{array}{l}\text { Daily operational } \\
\text { collaboration }\end{array}$ & Yes \\
\hline 7 & $\begin{array}{l}\text { Understanding that } \\
\text { customers need integrated } \\
\text { services, therefore three } \\
\text { firms operating as one. }\end{array}$ & $\begin{array}{l}\text { Delivering integrated } \\
\text { energy services }\end{array}$ & $\begin{array}{l}\text { Top managerial } \\
\text { collaborations and } \\
\text { daily operational } \\
\text { collaboration }\end{array}$ & Yes \\
\hline
\end{tabular}

\section{Understanding customers' needs}

The spin-off informants emphasized the importance of understanding both customers' needs or customer's customers' needs, and the potential challenges in serving them. This understanding occurred through a variety of means. In certain spin-off cases, senior personnel had previous work experience with the same type of companies that they now were targeting as customers: "Both I and my colleague have been working at major oil and gas companies [i.e., companies holding licenses to operate and/or being operators of oil and gas fields] and have first-hand knowledge of both their technological needs and difficulties of implementation," (Case 4, CEO, child firm). "I have worked with machining. I started in 1998, so I've been here a while. Before I took over the child company I was head of another child company [of the mother firm]" (Case 1, CEO, child firm).

In other cases, the understanding was said to originate from decades of working with the same type of customers: "The Company started out serving the oil and gas business 40 years ago. We know the needs of the different actors of the business" (Case 5, CFO, parent firm). "It's a combination of all the knowledge we have gained over many years as a company. But remember that even though we took over in 2004, the company goes back to 1966. There are many people who have been here for 30 years. They have good knowledge in creating products for the offshore industry because we have only focused on sea and offshore. (Case 1, CEO, parent firm)

In certain spin-off cases, the companies' understanding of the customers was completed by direct encounters with customer's customers, with possible users, and end customers: "Our experience as an energy utility has 
taught us how to provide customers with different kinds of services through cables. To be able to provide services such as alarms and so on for the elderly, we sat down with nurses from the local councils to learn from their experiences" (Case 2, CEO, child firm). "The ship bridge solutions, we had an idea to create a better working environment for those on board. Make it tidy, interchangeable and flexible so customers could choose instrumentation and adapt the bridge solutions to their needs in a simple way" (Case 1, CEO, parent firm). "All employees have to understand how (customer's) business works. Every employee here has a good business sense. It is important to us. When the CEO of a big shipping company calls and says there's something wrong with our billing system, the employee who answers the phone has to understand what the CEO is talking about" (Case 2, CEO, parent firm).

Understanding the customers and their needs from years of experience relates to organizing the practices and the general understandings (Schatzki, 2010). The general understandings refer to the treatment of third persons, tact, courtesy and matters germane to the practices, which are clearly revealed through understanding the customers.

\section{Identifying a market gap}

We found that the spin-off entrepreneurs had identified a gap in the marketplace: "We know there is a gap here, that there is a market for it. Those who had the system were Cisco, and they withdrew it [the system] and I don't think they withdrew it because it was bad. I think they withdrew it because they understood the idea was destructive to their existing business" (Case 6, COO, parent firm). "For our clients, it is advantageous to contact us because they can buy all services from one company. Otherwise, the client must first consult and write a contract with company $A$, then go on to the next company, to $B$, and so on" (Case 3, CEO, child firm).

Viewing the gap in the market that appeared after another firm left or before the development begins is a common trait: "The development starts when one sees a need. The seller sees a need for a new solution for the subsea cameras or that the well-boats need to control the fish when they are in the tanks. Then, 'we need a new camera' he says. Then, we take a spin-off from the camera, and we make one that is light intensive. Lots of incremental products come out of what we already have" (Case 1, CEO, parent firm).

Others receive enquiries and understand the market potential during the development:

"We have received enquiries from China.... We have been in Indonesia and Malaysia... we have been in Brunei several times and I have given presentations in Brunei.... Well, the market for offshore water, as I have said 
I have been in Saudi Arabia several times, where they have an enormous installation where they produce and lead water to oilfields in the west part of Saudi Arabia.... Only the offshore market in total globally regarding water injection, there are estimates of about 60-70 billion dollars per year. If we have a technology that is better than our competitors, then there are some percentages of these..." (Case 4, CEO, child firm).

Identifying a market gap requires understanding possibilities in relation to the products that can be offered. Identifying a gap is important to be able to believe in and develop the products or solutions to offer. To fulfil customers' needs and to develop the product, suppliers are involved through collaboration.

\section{Collaborating with suppliers}

The spin-offs relied heavily on the successful involvement of and collaboration with suppliers. To the extent that the spin-off company's product is something that must be developed, there were extensive collaborations with technical suppliers, often mechanical or electronic workshops. These suppliers help develop and test prototypes and were viewed as an integral part of the innovation process. In the cases where the suppliers took part from the idea stage and to full production, they co-created the product: "We have our supplier here in the region, which is a highly skilled business, which can take things from the very idea stage and aspect stage to prototype and full production and mass production" (Case 6, CEO, parent firm).

The important role of suppliers for prototyping, servicing, launching and commercializing the spin-off's service and product is highlighted: "It's a combination we use...it's a skill to play on. We use very competent companies that we work with, while we do a lot ourselves. The civil engineers here, they must be practical and we hire in electricians and mechanics.... However, it is especially when we are in the pilot test stage... I have two rocket scientists who work here for me. One has built electronics; the other has programmed control systems for missiles.... Now we go from pilot to industrial activities.... We have a company that, among other things, also makes electronics for F16 fighters; they are helping with the design, making the power supply that we will use" (Case 4, CEO, child firm).

The collaboration with suppliers was extensive. When inquiring into how the involvement of suppliers related to the spin-off, the informants stressed a close collaboration. "The idea came from a local maritime electronic company, who collaborated with a local ship design company. The person said: 'It is a large market, but we cannot either draw or manufacture this kind of ship bridge solution, but we want to sell and market the product'. This 
kind of cooperation we have had for years" (Case 1, CEO, parent firm). Most companies emphasized that they preferred using local suppliers so that they could follow the process closely. "To build the sensors we need, we use our supplier located not far away" (Case 2, CEO, child firm).

In the following, we make a division between operational collaboration and top managerial collaboration. We first emphasize cases in which the collaboration has been successful, and then turn to cases in which the collaboration has stalled.

\section{Operational collaboration}

There were many accounts of successful operational collaboration between the spin-offs and their suppliers: "Those who have been closest to the collaboration have had daily contact with the spin-off, on the technical side. We have weekly phone meetings also on the technical side regarding the development. And commercially, there have been weekly contacts there too" (Case 6, third party). "We are three companies that work closely together. We have three marketing departments... to work with those two companies with the most experience in the region is an asset. So yes, we have weight" (Case 7, CEO, child firm). "We began to work on this idea (bridge solution). We had some knowledge about it, and we worked closely with him [engineer at a ship design company]) and we worked closely with another company within ship consulting" (Case 1, CEO, parent firm).

With regard to the occasions when a spin-off did not work, we found that in Case 5, the collaboration with the supplier was not successful. We were told from different perspectives that this lack of collaboration was the main reason why the top management of the parent firm dissolved the entire spin-off (for an exposition of the managerial involvement and its role in the spin-off, please refer to the twin paper): "So we agreed on the basic premises. There were three partners here. One supplier had the main contract. In addition, we had to go through this supplier to talk with the third firm. A bit awkward really. And this was one of the reasons why it did not work out in the end. Too many special interests" (Case 5, CEO, child firm). "The other supplier company was very clear that they wanted to be part of this and that the spinoff company could use the supplier company. So the supplier company was in the same situation as the spin-off firm. They have not called off the deal, but they clearly said 'we have not managed to reach our goals to collaborate with an oil company, and people who can work with us. Therefore, we do not ask for exclusivity any longer'" (Case 5, third party). Both the child firm and the third party explained how a lack of operational collaboration with the supplier was a large part of the reason why the spin-off did not succeed. 
Top managerial collaboration

Collaboration with suppliers also occurred at a managerial level. Problems, disagreements or deviations from existing plans were elevated to a managerial level in order to secure collaboration between partners: "We managers, together with the managers of the suppliers, we are able to sit down there and talk... when we disagree on something then, I say 'ok, but then you owe me two pints', 'OK then'. You must be at a level that makes you flexible.....Are you too inflexible and begin to bill? It's guaranteed to become troublesome. You cannot capture everything in such large projects. We are talking about projects of the size of 100 million in total. And then we cannot start going bananas because someone or something is not going according to plan. You need to go up one level to the managerial. Then, you have to look a little bigger on it.... The balancing act I think is important.... In each project, it is impossible in advance to know about everything. But we are very clear that we do not accept turmoil in the projects. So, when things occur, it just gets noted down, and so we, [at a managerial level] treat it afterwards, so that it is something we must learn for the next time. And the economic bit in between here, we have written an agreement on how to deal with things. And then we left it up to me and the other manager, and then he and I agreed. In that way, the operational level is not sitting and arguing about the 10 thousand" (Case 7, CEO, parent 2).

Successful collaboration with customers is also a managerial strategy: "We say it to both customers and suppliers; we do not want to replace suppliers or customers. We do not believe that it gives us something of value in the long term. We want long-term relationships. And we choose to prioritize those customers who prioritize us. So, that...there have been some quite hectic times here. Sometimes, customers come with a project and I tend to say that 'Basically, if it is only this project, then it is not interesting for us'. Because we have no faith in prioritizing disposable connections. If we see an opportunity to have a cooperation over time, then we want to be a part" (Case 7, CEO, parent 1).

Supplier collaboration at a managerial level appears to be important for successful partnerships. A lack of successful supplier collaboration exposes how important it is for the spin-offs: "We saw that the willingness to be involved long term was not big enough. Supplier A had trouble doing what they said they would do. To be part of building multipurpose buildings that would be large enough facilities for all of us and with a cluster effect immediately. It was not implemented, and it was, excuse the expression, a bit amateurish and a dilatory treatment of this because it goes a little beyond the level of competence they have really.... And then supplier $B$ who thought that we should do everything... writing back to us that 'maybe this can be difficult, 
you should create $x x x$, you should do...', it was difficult for our board to strategically burn for the matter. So, that was why the tripartite collaboration was dissolved ... The location is ideal, the investments are ideal, there are many things that are ideal. However, the structured partnership model... it became an enemy. It looked very good to begin with, but I guess when you look back a year from now, one of those suppliers are gone" (Case 5, CEO, child firm).

Due to a lack of successful supplier collaboration, the board of Case 5 did not approve further operations; Case 5 as a spin-off was dissolved, and the employees returned to the parent firm. Successful collaboration with suppliers both at an operational and at a managerial level is shown to be highly important for spin-offs.

\section{DISCUSSION}

We set out to answer the following research question: How do spin-offs relate to customers and suppliers? We found that understanding customers and identifying market gaps involved general understanding from practice theory, whereas collaborating with suppliers exposed the net ties. Our findings reveal how customers and suppliers are involved in spin-offs. Practice theory's strength is to grasp which activities are performed and the practices they form. The nets, the actors' relations and implications for the spin-offs when not successful demonstrate how these are important.

The findings elaborate upon and extend innovation literature and perspectives on customer focus and supplier involvement. Our findings show that customer understanding is highly important for the spin-off to be successful. This finding is in accord with the literature on innovation, in which customer focus is an integral component (Chesbrough, 2003; Chesbrough, 2006; Danneels, 2002; Fjeldstad et al., 2012; Foss et al., 2011). This finding is not surprising; however, the extensive collaboration between the spin-offs and their suppliers is more of a surprise. The important role of suppliers for prototyping, servicing, launching and commercializing the spin-off's service and product was found to be critical. Whereas our findings show that suppliers play a key role in providing technological knowledge to the spin-offs, Clarysse et al. (2011) found that the technological knowledge characteristics of the spin-off's performance were found within the spin-off firm. Thus, we extend existing spin-off literature by exposing that technological knowledge critical to the spin-off often stems from suppliers.

Our findings of the close collaboration between spin-offs and suppliers are in line with what Baldwin and von Hippel (2011) denote as open collaborative projects in which the contributors share the work. We exposed 
how the suppliers are participating as co-developers and co-creators during prototyping, servicing, launching and commercializing the spin-off's service and product. In several cases, the suppliers even shared the financial burden for the product, systems and service development. In addition, the practices involved assuring close collaboration at all levels. There were daily technical and operational collaborations, managerial collaboration and board-level collaboration between the spin-offs and their suppliers. Thus, our findings extend Baldwin and von Hippel's (2011) understanding of open collaborative projects in specifying how suppliers are participating both at an operational and a managerial level. To the spin-off literature, our findings extend the entrepreneurship and innovation field (Wallin, 2012) regarding external entrepreneurial collaboration (Hellmann, 2007).

Our contribution to practice theory in relation to the perpetuation of an organization is the focus on inter-organizational practices. First, we found that the general understanding is highly important for customer relations and for identifying a market gap. Second, the nets to the suppliers, both at an operational and at a managerial level, exposed the activities involved and how the actors are linked through these ties. There were daily chains of action between the spin-offs and the suppliers at an operational level. When there were disagreements, these were discussed at a managerial level and occasionally taken to the boards. On occasions in which there was an excessive quantity of 'special interests', or in which the supplier failed to deliver, the spin-off was dissolved, as in Case 5. In line with Schatzki, who emphasized that the harmonious, competitive and conflicting interactions during the chains of action among the nets is important to uncover (Schatzki, 2005 , p. 476), we found that the interactions were addressed at all levels, and when the interactions were overly conflicting, the ties were cut, and the spinoff was dissolved. Thus, the nets with suppliers are critical for successful spinoffs, and the practices of collaboration with suppliers are manifold. Thus, our contribution to interorganizational collaboration practices is that we found that the practices involved daily operational and technical collaboration as well as managerial collaboration. In accordance with Levina and Vaast (2008), these shared practices were created around joint development work and enabled participants to identify with each other and with their shared work. Our contribution to this new research stream is the uncovering of operational and managerial collaboration for the spin-offs to be dissolved or successful.

\section{CONCLUSION}

This paper contributes to interorganizational collaboration practices, innovation literature and to perspectives on customer co-creation and 
supplier involvement. Suppliers who will collaborate are important for the commercialization of a spin-off, and the interorganizational collaboration practices are extensive. The strength of the empirical material is the triangular view of the parent firms, the child firms and third parties that have been involved during the spinning off. A limitation of this study is that we have not been able to follow the practices of collaboration over time. Instead, we addressed the activities of collaboration in retrospect with several spin-off cases to identify the phenomena of how spin-offs relate to customers and suppliers (Schatzki, 2016). Future studies could follow the interorganizational collaboration practices between a spin-off and a supplier to uncover how the nets develop in time and space. How the nets elaborate and how the different ties between the spin-offs and the suppliers develop are unresolved questions for future research.

\section{References}

Alvesson, M., \& Kärreman, D. (2007). Constructing mystery: Empirical matters in theory development. Academy of Management Review, 32(4), 12651281.

Alvesson, M., \& Kärreman, D. (2011). Qualitative Research and Theory Development. Mystery as Method. London: Sage Publications Ltd.

Baldwin, C., \& von Hippel, E. (2011). Modeling a paradigm shift: From producer innovation to user and open collaborative innovation. Organization Science, 22(6), 1399-1417.

Berends, H., van Burg, E., \& van Raaij, E. M. (2011). Contacts and contracts: Cross-level network dynamics in the development of an aircraft material. Organization Science, 22(4), 940-960.

Bergh, D. D., Johnson, R. A., \& Dewitt, R.-L. (2008). Restructuring through spin-off or sell-off: transforming information asymmetries into financial gain. Strategic Management Journal, 29(2), 133-148.

Bergh, D. D., \& Lim, E. N.-K. (2008). Learning how to restructure: absorptive capacity and improvisational views of restructuring actions and performance. Strategic Management Journal, 29(6), 593-616.

Bruneel, J., Van de Velde, E., \& Clarysse, B. (2013). Impact of the type of corporate spin-off on growth. Entrepreneurship: Theory \& Practice, 37(4), 943-959.

Chesbrough, H. W. (2002). Graceful exits and missed opportunities: Xerox's management of its technology spin-off organizations. Business History Review, 76(4), 803-837.

Chesbrough, H. W. (2003). Open Innovation: The New Imperative for Creating and Profiting from Technology. Boston: Harvard Business School Press.

Chesbrough, H. W. (2006). Open Business Models: How to Thrive in the New Innovation Landscape. Boston, MA.: Harvard Business School Press. 
Chesbrough, H. W. (2011). Open Services Innovation: Rethinking Your Business to Grow and Compete in a New Era. San Francisco Jossey- Bass, A Wiley Imprint.

Chesbrough, H. W., \& Crowther, A. K. (2006). Beyond high-tech: Early adopters of open innovation in other industries. R\&D Management, 36(3), 229-236.

Chien, S. H., \& Chen, J. J. (2010). Supplier involvement and customer involvement effect on new product development success in the financial industry. The Services Industries Journal, 30(2), 185-201.

Clarysse, B., Wright, M., \& Van de Velde, E. (2011). Entrepreneurial Origin, technological knowledge, and the growth of spin-off companies. Journal of Management Studies, 48(6), 1420-1442.

Danneels, E. (2002). The dynamics of product innovation and firm competences. Strategic Management Journal, 23(12), 1095.

De Cleyn, S. H., \& Braet, J. (2010). The evolution of spin-off ventures: An integrated model. International Journal of Innovation \& Technology Management, 7(1), 53-70.

Fjeldstad, O. D., Snow, C., Miles, M. B., \& Lettl, C. (2012). The architecture of collaboration: Organizing resources among large sets of actors. Strategic Management Joumal, forthcoming.

Foss, N. J., Laursen, K., \& Pedersen, T. (2011). Linking customer interaction and innovation: The mediating role of new organizational practices. Organization Science, 22(4), 980-999.

Handfield, R. B. (1999). Involving customers in new product development. California Management Review, 42(1), 59-82.

Hellmann, T. (2007). When Do Employees Become Entrepreneurs? Management Science, 53(6), 919-933.

Jaakkola, E., \& Halinen, A. (2006). Problem solving within professional services: Evidence from the medical field. International Journal of Service Industry Management, 17(5), 409-429.

Johannisson, B. (2011). Towards a practice theory of entrepreneuring. Small Business Economics, 36(2), 135-150.

Johannisson, B. (2012). Tracking the everyday practices of societal entrepreneuring. In K. Berglund, B. Johannisson, \& B. Schwartz (Eds.), Societal entrepreneurship: positioning, penetrating, promoting (pp. 6088). Cheltenham, UK: Edward Elgar Publishing, Inc.

Johannisson, B. (2014). The practice approach and interactive research in entrepreneurship and small-scale venturing. In A. Carsrud \& $M$. Brännback (Eds.), Handbook of Research Methods and Applications in Entrepreneurship and Small Business (pp. 228-258). Cheltenham, UK: Edward Elgar Publishing, Inc.

Keating, A., Geiger, S., \& McLoughlin, D. (2014). Riding the practice waves: Social resourcing practices during new venture development. Entrepreneurship: Theory \& Practice, 38(5), 1207-1235. 
Levina, N. (2005). Collaborating on multiparty information systems development projects: A collective reflection-in-action view. Information Systems Research, 16(2), 109-130.

Levina, N., \& Vaast, E. (2005). The emergence of boundary spanning competence in practice: Implications for implementation and use of information systems. MIS Quarterly, 29(2), 335-363.

Levina, N., \& Vaast, E. (2008). Innovating of doing as told? Status differences and overlapping boundaries in offshore collaboration. MIS Quarterly, 32(2), 307-332.

Mills, P. K., Chase, R. B., \& Margulies, N. (1983). Motivating the client employee system as a service production strategy. Academy of Management Review, 8(2), 301-310.

Pierce, C. S. (1978). Pragmatism and abduction. In C. Hartshorne \& P. Weiss (Eds.), Collected papers (Vol. V, pp. 180-212). Cambridge, MA: Harvard University Press.

Rasmussen, E., Mosey, S., \& Wright, M. (2011). The evolution of entrepreneurial competencies: A longitudinal study of university spin-off venture emergence. Journal of Management Studies, 48(6), 1314-1345.

Schatzki, T. (2005). Peripheral vision: The sites of organizations. Organization Studies, 26(3), 465-484.

Schatzki, T. (2006). On organizations as they happen. Organization Studies, 27(12), 1863-1873.

Schatzki, T. (2010). The Timespace of Human Activity: On Performance, Society, and History as Indeterminate Teleological Events. Lanham, MD.: Lexington Books.

Schatzki, T. (2012). A primer on practices: Theory and research. In J. Higgs, R. Barnett, S. Billett, M. Hutchings, \& F. Trede (Eds.), Practice-based education: Perspectives and strategies (pp. 13-26). Rotterdam: Sense Publishers.

Schatzki, T. (2013). The edge of change: On the emergence, persistence, and dissolution of practices. In E. Shove, \& N. Spurling (Eds.), Sustainable Practice: social theory and climate change (pp. 31-46). New York: Routledge.

Schatzki, T. (2016). Keeping Track of Large Social Phenomena. Geographische Zeitschrift, 104(1), 4-24.

Schatzki, T., Knorr Cetina, K. D., \& von Savigny, E. (Eds.). (2001). The Practice Turn in Contemporary Theory. London: Routledge.

Silverman, D. (2005). Doing Qualitative Research: A Practical Handbook. Los Angeles, Calif.: Sage.

Steyaert, C., \& Landström, H. (2011). Enacting entrepreneurship research in a pioneering, provocative and participative way: on the work of Bengt Johannisson. Small Business Economics, 36(2), 123-134.

Sydow, J., Windeler, A., Schubert, C., \& Möllering, G. (2012). Organizing R\&D consortia for path creation and extension: The case of semiconductor manufacturing technologies. Organization Studies, 33(7), 907-936. 
Wallin, M. W. (2012). The bibliometric structure of spin-off literature. Innovation: Management, Policy \& Practice, 14(2), 162-177.

Wasti, S. N., \& Liker, J. K. (1997). Risky business or competitive power: Supplier involvement in Japanese product design. Journal of Product Innovation Management, 14(337-355).

\begin{abstract}
Polish)
Artykuł dotyczy współpracy pomiędzy firmami spin-off a ich klientami i dostawcami. Materiał empiryczny dotyczqcy siedmiu przypadków firm spin-off wspieranych przez tradycyjnych uczestników branży, wskazano że dostawcy sq w znaczacym stopniu zaangażowani w rozwój innowacji, na których opierajq się firmy spin-off, jak również omówiono praktyki rozumienia klientów, identyfikowania luk rynkowych i współpracy $z$ dostawcami. Wkład do litertury dotyczqcej spótek odpryskowych polega na identyfikacji działań, które przyczyniaja się do sukcesu spin-offów, pozwalajq̨ na pogłębienie zrozumienia sposobów utrwalania organizacji i sieci relacji pomiędzy spin-offami i ich dostawcami.
\end{abstract}

Słowa kluczowe: korporacyjny spin-off, klienci, dostawcy, praktyki, ogólne rozumienie.

\title{
Biographical notes
}

Katja Maria Hydle is a senior research scientist at the International Research Institute of Stavanger. She received her PhD in Strategic Management from BI Norwegian Business School. Her research focuses on innovation, professional service work, organizational practices and multinational companies.

Kjersti Vikse Meland is a senior research scientist at Uni Research Polytec. Meland has an M.sc in marketing from Buskerud University College in Norway. Her research concentrates on innovation, entrepreneurship, clusters and regional development. Meland has extensive experience in research on innovation and regional development. 